\title{
The Impact of Bank Governance on Bank Performance in
}

\section{Pakistan}

\author{
Abid A. Burki ${ }^{*}$ and Shabbir Ahmad ${ }^{* *}$
}

\begin{abstract}
This study attempts to investigate the impact of changes in bank governance on bank performance in Pakistan. Governance changes entail the privatization and restructuring of state-owned banks, and the merger and acquisition of private and foreign banks. Using the concept of frontier efficiency, we adopt an empirical framework that allows us to study the impact of all governance reform variables in the same model. First, we estimate a stochastic cost frontier model using unbalanced panel data on commercial banks for the period 1991-2005. Second, we decompose banks' total factor productivity (TFP) change into its different components, using the estimated frontier. In general, the results show an improvement in banks' cost efficiency following changes in bank governance. We note that governance changes bring about an improvement in banks' TFP vis-à-vis that of banks that did not undergo governance changes. We find a declining trend in TFP change (TFPC), which could be a consequence of the banking industry's increased profitability. We also note that bank selection for governance changes has a mixed effect on TFPC, while bank consolidation seems to be more effective in improving TFPC.
\end{abstract}

Keywords: Bank Reform, Total Factor Productivity, Stochastic Frontier Model, Pakistan.

JEL Classification: D24, M31, J54.

\section{Introduction}

During the last two decades, Pakistan's banking sector has undergone structural changes as part of the phased reforms in the financial sector that were initiated in 1990/91. These reforms paid attention to, among other things, prudential regulations that authorized (i) the opening of several new private and foreign banks, (ii) the restructuring and downsizing of state-owned banks before being privatized, and (ii) reforms

\footnotetext{
* Department of Economics, Lahore University of Management Sciences.

** Department of Economics, University of Queensland, Brisbane, Australia.
} 
relating to mergers and acquisitions (M\&A) that helped consolidate private and foreign banks. These reforms led to a dramatic decrease in the asset share of state-owned banks, from 93 percent in 1990 to only 22 percent in 2004. In the same period, the share of private banks increased from 0 to 67.5 percent, and that of foreign banks increased from 6.7 to 10.4 percent (State Bank of Pakistan, 2004). The reforms also allowed foreign banks to compete freely with domestic banks.

Empirical research on the impact of bank governance on bank performance remains limited, but it does have a wider appeal. The vast body of literature on banking efficiency and productivity provides insights into variables that have significantly affected banks' performance in the past. However, there is little consensus on how the changing structure of the banking industry impacts banking sector performance in different countries. Our goal is to examine the impact of changes in bank governance on bank performance in Pakistan, by looking at four broad areas: (i) the extent to which market liberalization has affected the performance of domestic and foreign banks, as measured by efficiency and total factor productivity (TFP); (ii) the role of privatization in postprivatization efficiency and productivity in the short and long run; (iii) how the restructuring of state-owned banks has affected their performance; and (iv) how M\&A reforms have affected post-merger performance. This article extends the results of Burki and Ahmad (2010) by calculating TFP change (TFPC) and decomposing it into its different constituents.

While a large body of literature has documented the comparative efficiency of state-owned, private, and foreign banks in transition and developing countries, it offers mixed results (see, for example, Burki \& Ahmad, 2010; Burki \& Niazi, 2010; Hauner \& Peiris, 2007; Lensink, Meesters, \& Naaborg, 2008; Yildrim \& Philippatos, 2007). There is convincing evidence that state-owned banks are the least efficient in these countries, but evidence on the relative efficiency of private and foreign banks is, at best, ambiguous (see Berger et al., 2004; Bhattacharya, Lovell, \& Sahay, 1997; Isik \& Hassan, 2002). The two studies that use data on Pakistani banks also provide mixed results: Patti and Hardy (2005) find that foreign banks in Pakistan are the most profit-efficient, followed by private banks, and then by state-owned banks. However, the average cost-efficiency of these banks appears to be similar, in contrast to the findings of Burki and Niazi (2010) who conclude that foreign banks' cost efficiency is superior to that of private and state-owned banks. Burki and Ahmad (2010) show that private and foreign banks in Pakistan are more cost-efficient than state-owned banks. Empirical evidence on the impact 
of privatization on banks' performance in developing countries also fails to provide a clear picture-some studies have suggested that privatization improves performance but evidence from other studies indicates no change in performance (Boubakri, Cosset, \& Guedhami, 2005; Clarke, Cull, \& Shirley, 2005; Patti \& Hardy, 2005; Williams \& Nguyen, 2005). Financial liberalization and deregulation have helped diversify bank portfolios, but they have also introduced new challenges to risk management and product quality.

Studies on TFP in the banking sector are confined mostly to nonparametric approaches to computing the Malmquist index of TFPC. However, some studies have used econometric methods to compute TFP change and its components (see, among others, Grifell-Tatjé \& Lovell, 1996; Humphrey, 1992; Orea, 2002). Berger and Mester (2001) have reinterpreted the literature by proposing a parametric method to decompose total changes in cost over time into portions due to changes in business conditions and changes in bank productivity. A number of studies have used various econometric model specifications to estimate either TFP growth or technological progress in US banking during the 1980s and 1990s (see Bauer, Berger, \& Humphrey, 1993; Humphrey, 1993; Humphrey \& Pulley, 1997). Generally, this body of literature has found little evidence of productivity growth, whereas evidence on technological progress has been mixed.

Some studies measure scale and scope economies, and indicate the presence of scale economies in the US banking sector (see Berger, Hanweck, \& Humphrey, 1987; Berger \& Mester, 1997), while others explore the effects of M\&A on US banking (see Berger \& Humphrey, 1992; Berger \& Mester, 2003; Hughes, Lang, Mester, \& Moon, 1999). Studies investigating the efficiency and productivity of the banking industry in Europe include Fries and Taci (2005), Grigorian and Manole (2002), Hasan and Marton (2000), Kraft and Tirtiroglu (1998), Mertens and Urga (2001), and Opiela (2001).

Empirical research measuring the efficiency of banks in developing countries gained momentum only in the late 1990s and early 2000s. Such studies include Bhattacharya et al. (1997) for India; Burki and Niazi (2010), Burki and Ahmad (2010), and Patti and Hardy (2005) for Pakistan; Gilbert and Wilson (1998) for Korea; Isik and Hassan (2002) for Turkey; Leightner and Lovell (1998) for Thailand; and Rezvanian and Mehdian (2002) for Singapore. Some focus on the impact of financial liberalization (see Katib \& Mathews, 2000; Okuda \& Mieno, 1999), or ownership structure and efficiency (Hao, Hunter, \& Yang, 2001; Leightner 
\& Lovell, 1998). Studies on banking deregulation, such as Gilbert and Wilson (1998), show that it has a positive impact on banking efficiency and productivity. ${ }^{1}$

Most studies on the banking sector emphasize technical efficiency effects, although some also take into account allocative inefficiency. Only a few studies have analyzed TFPCs in the banking sector in developing countries, and decomposed TFP into technical change (TC), and technical and scale efficiency change (SEC) using the Malmquist index. Allocative efficiency change (AEC) becomes important particularly when state control lessens following the deregulation process, along with other governance changes.

In this study, we decompose TFPC into cost efficiency change (CEC), TC, SEC, and AEC by recent bank ownership and governance changes in Pakistan. Against this backdrop, we investigate the impact of changes in bank governance on bank performance. First, we estimate a stochastic cost frontier model using unbalanced panel data on commercial banks in Pakistan for the period 1991-2005. Second, we decompose TFPC into its components, using the estimated stochastic cost frontier model.

Section II presents the methodology used. Section III describes the data and its variables. Section IV considers the estimation results, while Section V examines TFPC and its decomposition. Section VI deals with TFPC by bank governance variables, and Section VII presents the study's conclusions.

\section{Methodology}

Our measure of technical inefficiency is based on the stochastic cost frontier model for unbalanced panel data that allows time-varying bank effects (see Battese \& Coelli, 1995).

The model can be written as

$$
\ln C_{t t}=C\left(q_{t}, w_{t t}, \tau, \beta\right)+v_{r t}+u_{t}
$$

\footnotetext{
${ }^{1}$ Katib and Mathews (2000) and Williams and Intarachote (2002), however, have concluded that financial liberalization affects banking efficiency negatively as operational costs increase. They have emphasized that elements of competitiveness and liberalization are important in developing countries because of the concentrated ownership of banks and the state support for them.
} 
The subscript $n$ indexes a sample bank $(n=1, \ldots, N)$, and $t$ indexes time period $(t=1, \ldots, T) ;{ }^{2} C_{n t}$ is the observed total cost of production for the $n$th sample bank in the $t$ th time period; $q_{n t}$ is a vector of bank outputs; $w_{n t}$ is a vector of input prices of known functions of cost and other explanatory variables linked with the $n$th bank in the $t$ th time period; $\tau$ is the time trend; $C\left(q_{n t}, w_{n t}, \tau ; \beta\right)$ is the assumed functional form; and $\beta$ is a vector of unknown parameters to be estimated. As usual in the frontier literature, the stochastic composite error term in Equation (1) is decomposed into $v_{n t}$ and $u_{n t}$ where $v_{n t}$ represents the stochastic random error component that captures the effects of exogenous shocks to the cost function due to factors beyond the bank's control, and is assumed to be iid $N\left(0, \sigma_{v}^{2}\right)$. Moreover, $v_{n t}$ is independently distributed of $u_{n t}$.

The technical inefficiency term, $u_{n t}$, is a nonnegative random variable that captures the bank- and time-specific cost-inefficiency effects and reflects the extent to which the cost of the $n$th bank in the $t$ th time period exceeds the minimum cost defined by the frontier. A higher value for $u$ indicates an increase in technical inefficiency. When $u$ equals 0 , the bank is fully technically efficient because it is on the cost frontier. We further assume that $u_{n t}$ is independently distributed, such that $u_{n t}$ is obtained by truncation at 0 . In effect, the technical inefficiency variable, $u_{n t}$, for each bank in Equation (1) could be replaced by a linear function of explanatory variables reflecting firm- and time-specific characteristics specified by:

$$
u_{n t}=\phi z_{n t}+\varepsilon_{n t}
$$

Here, $\phi$ is a vector of unknown bank- and time-specific parameter estimates associated with banks' technical inefficiency and $\varepsilon_{n t}$ is an unobservable random variable obtained by truncating the normal distribution with mean 0 and variance $\sigma^{2}$. The point of truncation occurs at $-\phi z_{n t}$ or $\varepsilon_{n t} \geq-\phi z_{n t} \cdot 3$

The functional form employed in the empirical analysis is the stochastic frontier translog cost for the panel data, and is written as

\footnotetext{
${ }^{2}$ Not all the banks in our sample are observed for all $T$ time periods in this model.

${ }^{3}$ The maximum likelihood function is given in the appendix to Battese and Coelli (1993) for the production function. However, the likelihood function for cost specification can be derived merely by altering the signs.
} 


$$
\begin{aligned}
& \ln C_{n t}= \alpha_{0} \\
&+\sum_{r=1}^{3} \alpha_{r} \ln w_{m t}+\sum_{m=1}^{2} \beta_{m} \ln q_{m t}+\psi_{\tau} \tau_{n t}+\psi_{\tau \tau} \tau_{n t}^{2}+\sum_{r=1}^{3} \sum_{s=1}^{3} \alpha_{r s} \ln w_{m t} \ln w_{s t t}+\frac{1}{2} \sum_{m=1}^{2} \sum_{k=1}^{2} \beta_{m k} \ln q_{m t} \ln q_{l k t} \\
&+\sum_{r=1}^{3} \sum_{m=1}^{2} \gamma_{m} \ln w_{m t} \ln q_{m t}+\sum_{r=1}^{3} \delta_{r t} \ln w_{m t} \tau+\sum_{m=1}^{2} \gamma_{n t} \ln q_{m t} \tau+v_{n t}+u_{n t}
\end{aligned}
$$

The subscripts $r, s$ denote factor prices; $m, n$ denote outputs; $t$ refers to the time period; $C_{n t}$ is the total cost; and $\tau$ is a time trend variable for the year of observation for each bank, which accounts for the effects of disembodied technological progress in the stochastic frontier model and time-varying inefficiency effects in the inefficiency model.

To test the impact of changes in bank governance on banks' technical inefficiency, we specify a technical inefficiency effects model using a linear function of explanatory variables. We allow the effects of changes in governance by following Berger et al. (2005) and include different types of governance-change attributes given by

$$
\begin{aligned}
& u_{n t}=\phi_{0}+\sum_{j=1}^{2} \phi_{j} \text { STATIC }+\sum_{k=3}^{5} \phi_{k} \text { SELECTION }+\sum_{l=6}^{8} \phi_{l} \text { SR_DYNAMIC } \\
& +\sum_{\mathrm{m}=9}^{11} \phi_{\mathrm{m}} \text { LR_DYNAMIC }+\phi_{12} \ln \left(A_{n t-1}\right)+\delta_{13}\left(\tau_{n t}\right)+\varepsilon_{n t}
\end{aligned}
$$

STATIC refers to static governance change variables: private banks with no governance change (base category), foreign banks with no governance change, and state-owned banks with no governance change. SELECTION is a vector representing three selection variables: (i) selected for privatization, (ii) selected for restructuring, and (iii) selected for M\&A. SR_DYNAMIC represents the short-run effects of governance change in terms of banks that underwent privatization, restructuring, or M\&A; and LR_DYNAMIC indicates the long-run effects of governance change in terms of years after privatization, years after restructuring, and years after M\&A.

We estimate the stochastic frontier model in Equation (3) along with the model for bank-specific time-varying technical inefficiency effects in Equation (4) simultaneously, using the maximum likelihood function given in Battese and Coelli (1993). The parameter estimates of the translog cost frontier are obtained by imposing symmetry conditions on the cross-price and cross-output effects and homogeneity of degree one in input prices, given $q_{n t}$ and $\tau$. 
Next, we use parameter estimates for TFP, which can be measured as the ratio of output to input index. This indicates how much output can be achieved using the given input index, TFP $P_{n}=q_{n t} / x_{n t}$, where $q_{n t}$ and $x_{n t}$ are the outputs and inputs of the $n$th bank, respectively. Thus, the change in TFP is the difference between the growth of output to growth of input index. In other words, it can be written as the ratio of TFP in period 1 to period 0 as follows:

$$
\operatorname{TFPC}_{n 0, n 1}=\frac{\operatorname{TFPC}_{n 1}}{\operatorname{TFPC}_{n 0}}
$$

TFPC $_{n}$ represents the TFPC of the $n$th bank between periods 0 and 1 . Equation (5) represents TFP in the context of shifts in the cost frontier. This shift in the cost frontier is the result of a change in technology, change in scale economies, and change in cost efficiency. Using the underlying technology, the TFPC measure can be decomposed into CEC, TC, and SEC. Therefore, the change in TFP of the $n$th bank can be written as:

$$
T F P C_{n}=C E C_{n} \times T C_{n} \times S E C_{n}
$$

Since we have used the translog cost frontier in Equation (3) in our estimation, the corresponding Tornqvist TFP index is a convenient representation of the underlying technology. The Tornqvist index of TFPC in two periods can be expressed as:

$\ln \left(\frac{\operatorname{TFP}_{n 1}}{\operatorname{TFP}_{n 0}}\right)=\frac{1}{2} \sum_{m=1}^{M}\left[\left(r_{m n 1}+r_{m n 0}\right) \cdot\left(q_{m n 1}-q_{m n 0}\right)\right]+\frac{1}{2} \sum_{k=1}^{K}\left[\left(s_{k n 1}+s_{k n 0}\right) \cdot\left(x_{k n 1}-x_{k n 0}\right)\right]$

Here, $r_{m n 1}$ is the revenue share of the $m$ th output of the $n$th bank in period 1 , and $s_{k n 1}$ is the share of the $k$ th input for the $n$th bank in period 1 . Since the translog frontier is an approximation of the Tornqvist index, using the translog cost function in Equation (3) yields the following expression for the components of the TFP index:

$$
\begin{aligned}
& \ln \left(\frac{T F P_{n 1}}{T F P_{n 0}}\right)=\ln \left(\frac{C E_{n 0}}{C E_{n 1}}\right)-\frac{1}{2}\left(\frac{\partial C_{n 0}}{\partial t}\right)+\left(\frac{\partial C_{n 1}}{\partial t}\right)+\frac{1}{2} \sum_{m=1}^{M}\left[\left(S F_{n 0} \eta_{m n s}+S F_{n 1} \eta_{m n 1}\right) \cdot\left(q_{m n 1}-q_{m n 0}\right)\right] \\
& C E_{n t}=\exp \left(u_{n t}\right) ; \frac{\partial C_{n t}}{\partial t}=\psi_{\tau}+\psi_{\tau \tau} \tau+\sum_{r=1}^{3} \delta_{r t} \ln w_{r n t}+\sum_{m=1}^{2} \gamma_{m t} \ln q_{m n t} ; \quad \text { and } S F_{n 0}
\end{aligned}
$$

and $S F_{n 1}$ are scale factors for the $n$th bank in periods 0 and 1, respectively, and are represented by $S F_{m t}=\left(1-\eta_{m t}\right) / \eta_{m t}$ at each point in time where 
$\eta_{t}=\sum_{m=1}^{M} \eta_{n m t}$ and $\eta_{m t}$ is the cost elasticity with respect to the $m$ th output given by $\eta_{m n t}=\frac{\partial C_{n t}}{\partial y_{m n t}}=\beta_{m}+\beta_{m n} \ln q_{n n t}+\gamma_{r m} \ln w_{r n t}+\gamma_{m t} \tau$

The difference between the Tornqvist TFP index in Equation (7) and cost-based TFP index in Equation (8) is due to AEC. Therefore, to explain TFPC, it is important to take into account distortions in input and output mixes. AEC is described as follows:

$$
\begin{aligned}
A E C= & \frac{1}{2} \sum_{n=1}^{N}\left[\left\{\left(\pi_{m k s}-r_{m k s}\right)+\left(\pi_{m k t}-r_{m k t}\right)\right\}\right]\left(q_{m k t}-q_{m k s}\right) \\
& +\frac{1}{2} \sum_{n=1}^{N}\left[\left\{\left(\theta_{n k s}-s_{n k s}\right)+\left(\theta_{n k t}-s_{n k t}\right)\right\}\right]\left(w_{n k t}-w_{n k s}\right)
\end{aligned}
$$

where

$$
\begin{gathered}
\theta_{k n t}=\frac{\partial C_{i t}}{\partial w_{k i t}}=\alpha_{\gamma}+\alpha_{r s} \ln w_{r n t}+\gamma_{r m} \ln q_{m n t}+\delta_{r t} \tau ; \\
\theta_{k n t}=\frac{\partial C_{i t}}{\partial w_{k i t}}=\alpha_{\gamma}+\alpha_{r s} \ln w_{r n t}+\gamma_{r m} \ln q_{m n t}+\delta_{r t} \tau ; \\
\pi_{n m t}=\eta_{n m t} / \eta_{m t}, r_{m k t}, \text { and } \theta_{n k t} \text { and } s_{n k t} \text { are the cost-efficient and }
\end{gathered}
$$
observed shares of the bank's revenue and cost for the $m$ th output and $k$ th input, respectively. The first component of (9) accounts for allocative output mix efficiency: it shows the deviation of observed revenue shares, $r_{n k t}$, from efficient revenue shares. The second component is due to input mix allocative efficiency as the observed cost share deviates from the costefficient share. After taking into account the allocative (input, output) mixes efficiency, TFPC can be computed as follows:

$$
\mathrm{TFPC}_{n}^{*}=C E C_{n} \times \mathrm{TC}_{n} \times S E C_{n} \times A E C_{n}
$$


Now (9) becomes

$$
\begin{aligned}
\ln \left(T F P_{n 1} / T F P_{n 0}\right)= & \ln \left(C E_{n 0} / C E_{n 1}\right)-\frac{1}{2}\left[\left(\partial C_{n 0} / \partial t\right)+\left(\partial C_{n 1} / \partial t\right)\right] \\
& +\frac{1}{2} \sum_{m=1}^{M}\left[\left(S F_{n 0} \eta_{m n 0}+S F_{n 1} \eta_{m n 1}\right) \cdot\left(q_{m n 1}-q_{m n 0}\right)\right] \\
& +\frac{1}{2}\left\{\begin{array}{l}
\sum_{m=1}^{M}\left[\left\{\left(\pi_{m k 0}-r_{m k 0}\right)+\left(\pi_{m k 1}-r_{m k 1}\right)\right\}\right]\left(q_{m k 1}-q_{m k 0}\right) \\
\sum_{k=1}^{K}\left[\left\{\left(\theta_{n k 0}-s_{n k 0}\right)+\left(\theta_{n k 1}-s_{n k 1}\right)\right\}\right]\left(w_{n k 1}-w_{n k 0}\right)
\end{array}\right\}
\end{aligned}
$$

Equation (11) is different from (7) since we have allowed for allocative inefficiency change by adding the last term of allocative mixes inefficiency if market output shares are not equalized with shadow output shares. Similarly, the second part of the last term is due to allocative input mix efficiency which is nonzero when market input prices are different from shadow prices. However, if both input and output allocative inefficiencies are absent, then our TFP estimates will be the same as those obtained in Equation (7).

\section{Data and Variables}

We use a 15-year unbalanced panel dataset for 46 Pakistani banks from 1991-2005 for a total of 537 observations. The dataset includes all commercial banks that operated in Pakistan during this period. We adopt the intermediation approach because interest costs account for more than 70 percent of total costs in Pakistani banks. We use two outputs: (i) loans and advances $\left(q_{1}\right)$; and (ii) investments $\left(q_{2}\right)$; and construct three factor prices: (i) price of labor $\left(w_{1}\right)$, (ii) price of deposits, and (iii) price of operating cost $\left(w_{3}\right)$. The total cost of intermediation-as defined by Sealey and Lindley (1977), Drake and Weyman-Jones (1996), and Berger and Humphrey (1997)—includes interest expenses on deposits, subtracting service charges plus expenditures on other purchased inputs. We define these variables in Table 1.

\section{Estimation Results}

The maximum likelihood parameter estimates of the translog cost frontier and inefficiency effects model are obtained by simultaneously estimating Equation (3) and Equation (4), using FRONTIER 4.1 (see Coelli, 1996). For hypothesis tests regarding functional forms and model 
specification, we apply the generalized likelihood ratio test described in Coelli et al. (1998) where the asymptotic distribution of the likelihood ratio test is given by mixed- $\chi^{2}$ distribution, and the critical values are drawn from Kodde and Palm (1986).

Table 1: Definition of Inputs, Outputs, and Exogenous Variables

\begin{tabular}{|c|c|}
\hline Variables & Definition \\
\hline \multicolumn{2}{|l|}{ Cost Function } \\
\hline Total cost $(C)$ & $\begin{array}{l}\text { Wage bill, including directors' fees }+ \text { depreciation of } \\
\text { and repair to bank's property }+ \text { operating cost }+ \text { interest } \\
\text { paid on deposits and borrowing + operating cost. }\end{array}$ \\
\hline Investments $\left(q_{1}\right)$ & $\begin{array}{l}\text { Amount of investment made by the bank, consisting of } \\
\text { government securities, treasury bills, shares fully paid } \\
\text { up, debentures, bonds, and other investments, e.g., NIT } \\
\text { and gold. }\end{array}$ \\
\hline Loans and advances $\left(q_{2}\right)$ & $\begin{array}{l}\text { Value of loans and advances, including loans, cash } \\
\text { credits, overdrafts, and bills discounted and purchased. }\end{array}$ \\
\hline Price of labor $\left(w_{1}\right)$ & $\begin{array}{l}\text { Total expenditure on employees' salaries, including } \\
\text { directors' fees, divided by the total number of } \\
\text { employees. }\end{array}$ \\
\hline Price of financial capital $\left(w_{2}\right)$ & $\begin{array}{l}\text { Total interest paid on deposits and borrowing divided } \\
\text { by total deposits. }\end{array}$ \\
\hline Price of operating cost $\left(w_{3}\right)$ & Total operating cost divided by total assets. \\
\hline Time trend $(\tau)$ & $\begin{array}{l}\text { Simple time trend variable indicating the year of } \\
\text { observation involved. }\end{array}$ \\
\hline \multicolumn{2}{|l|}{ Inefficiency Equation } \\
\hline \multicolumn{2}{|l|}{ Static governance variables } \\
\hline $\begin{array}{l}\text { Private bank with no } \\
\text { governance change }\left(z_{0}\right)\end{array}$ & $\begin{array}{l}\text { Dummy }=1 \text { for all periods for a private bank if it } \\
\text { underwent no governance change during 1991-2005, } \\
\text { and }=0 \text { for all periods otherwise. }\end{array}$ \\
\hline $\begin{array}{l}\text { Foreign bank with no } \\
\text { governance change }\left(z_{1}\right)\end{array}$ & $\begin{array}{l}\text { Dummy }=1 \text { for all periods for a foreign bank if it } \\
\text { underwent no governance change during 1991-2005, } \\
\text { and = } 0 \text { for all periods otherwise. }\end{array}$ \\
\hline $\begin{array}{l}\text { State-owned bank with no } \\
\text { governance change }\left(z_{2}\right)\end{array}$ & $\begin{array}{l}\text { Dummy = } 1 \text { for all periods for a state-owned bank if it } \\
\text { underwent no governance change during 1991-2005, } \\
\text { and }=0 \text { for all periods otherwise. }\end{array}$ \\
\hline \multicolumn{2}{|l|}{ Banks selected for governance change } \\
\hline $\begin{array}{l}\text { Selected for privatization } \\
\left(z_{3}\right)\end{array}$ & $\begin{array}{l}\text { Dummy }=1 \text { for all periods for a bank that was selected } \\
\text { for privatization during } 1991-2005 \text {, and }=0 \text { for all } \\
\text { periods otherwise. (Note: If a bank was privatized after } \\
\text { restructuring, the variable is set to equal } 1 \text { because } \\
\text { privatization is considered a dominant event). }\end{array}$ \\
\hline
\end{tabular}




\begin{tabular}{|c|c|}
\hline $\begin{array}{l}\text { Selected for restructuring } \\
\left(z_{4}\right)\end{array}$ & $\begin{array}{l}\text { Dummy = } 1 \text { for all periods for a bank that was selected } \\
\text { for government restructuring (e.g., downsizing, } \\
\text { capital/equity injection, etc.) during 1991-2005, and =0 } \\
\text { for all periods otherwise. (Note: If a bank was privatized } \\
\text { after restructuring, the variable is set to equal } 0 \text { because } \\
\text { privatization is considered a dominant event). }\end{array}$ \\
\hline Selected for M\&A $\left(z_{5}\right)$ & $\begin{array}{l}\text { Dummy }=1 \text { for all periods for a bank that was selected } \\
\text { for domestic/foreign acquisition or merger during } \\
1991-2005, \text { and }=0 \text { for all periods otherwise. }\end{array}$ \\
\hline \multicolumn{2}{|c|}{ Variables measuring short-run effects of governance change } \\
\hline $\begin{array}{l}\text { Experienced privatization } \\
\left(z_{6}\right)\end{array}$ & $\begin{array}{l}\text { Dummy = } 1 \text { for all periods following privatization of a } \\
\text { bank starting in the next year after privatization, and = } \\
0 \text { for the year of privatization and prior to privatization. } \\
\text { Banks that did not undergo privatization are set to } \\
\text { equal } 0 \text { for all periods. }\end{array}$ \\
\hline $\begin{array}{l}\text { Experienced restructuring } \\
\left(z_{7}\right)\end{array}$ & $\begin{array}{l}\text { Dummy = } 1 \text { for all periods following restructuring of a } \\
\text { bank starting in the next year after restructuring, and = } \\
0 \text { for the year of restructuring and prior to } \\
\text { restructuring. Banks that did not undergo restructuring } \\
\text { are set to equal } 0 \text { for all periods. }\end{array}$ \\
\hline Experienced $\mathrm{M} \& \mathrm{~A}\left(z_{s}\right)$ & $\begin{array}{l}\text { Dummy }=1 \text { for all periods following M\&A of a bank } \\
\text { starting in the next year after M\&A, and }=0 \text { for the year } \\
\text { of M\&A and prior to M\&A. Banks that did not undergo } \\
\text { M\&A are set to equal } 0 \text { for all periods. }\end{array}$ \\
\hline \multicolumn{2}{|c|}{ Dynamic governance variables measuring long-run effects of governance change } \\
\hline Years after privatization $\left(z_{9}\right)$ & $\begin{array}{l}\text { Number of years since privatization of the bank took } \\
\text { place. Set to equal } 0 \text { for the year of and years prior to } \\
\text { privatization, and starts with } 1 \text { for the first year after } \\
\text { privatization, } 2 \text { for the second year and so on. Banks } \\
\text { that did not undergo privatization are set to equal } 0 \text { for } \\
\text { all periods. }\end{array}$ \\
\hline $\begin{array}{l}\text { Years after restructuring } \\
\left(z_{10}\right)\end{array}$ & $\begin{array}{l}\text { Number of years since restructuring of the bank took } \\
\text { place. Set to equal } 0 \text { for the year of and years prior to } \\
\text { restructuring, and starts with } 1 \text { for the first year after } \\
\text { restructuring, } 2 \text { for the second year and so on. Banks } \\
\text { that did not undergo restructuring are set to equal } 0 \text { for } \\
\text { all periods. }\end{array}$ \\
\hline Years after M\&A $\left(z_{11}\right)$ & $\begin{array}{l}\text { Number of years since M\&A of the bank took place. Set } \\
\text { to equal } 0 \text { for the year of and years prior to M\&A, and } \\
\text { starts with } 1 \text { for the first year after M\&A, } 2 \text { for the } \\
\text { second year and so on. Banks that did not undergo } \\
\text { M\&A are set to equal } 0 \text { for all periods. }\end{array}$ \\
\hline \multicolumn{2}{|l|}{ Other control variables } \\
\hline Log lagged assets $\left(\ln A_{t-1}\right)$ & $\begin{array}{l}\text { Natural log of bank assets after taking one-year lag for } \\
\text { each bank in constant 1999/2000 Pakistan rupees. }\end{array}$ \\
\hline Time trend $(\tau)$ & $\begin{array}{l}\text { Simple time trend variable indicating the year of } \\
\text { observation involved. }\end{array}$ \\
\hline
\end{tabular}


Our test results show that the null hypothesis that the correct functional form is Cobb-Douglas is rejected in favor of translog at the 1 percent level of statistical significance. Moreover, a generalized likelihood ratio test for the hypothesis that technical inefficiency effects are absent in our empirical specification $\left(H_{0}: \gamma=\delta_{0}=\ldots=\delta_{13}=0\right)$ is also rejected at the 1 percent level of statistical significance. This test result confirms that most banks in our sample are operating above the cost frontier. Finally, the null hypothesis that $\left(H_{0}: \delta_{1}=\ldots=\delta_{13}=0\right)$ implying that inefficiency variables in the model are jointly zero is also rejected.

Tables 2 and 3 present the estimated coefficients of the translog cost frontier imposing homogeneity and symmetry, along with the correlates of technical inefficiency. Our results are qualitatively similar to those of Burki and Ahmad (2010) even though the sample size and empirical specification is different. The positive signs for all first-order parameters in Table 2 suggest that banking costs rise with increases in the prices of factors and outputs. Next, we interpret the differential impact of bank governance changes on the technical inefficiency of the banks in our sample (see Table 3). Their mean technical inefficiency is 1.35 in the full model (see secondlast row in Table 2), which suggests that, on average, bank costs exceed the minimum-level frontier by 35 percent due to technical inefficiency. Since the dependent variable in Equation (4) is technical inefficiency (not efficiency), a negative (positive) sign on the estimated coefficients in Table 3 would indicate a decrease (increase) in technical inefficiency, or increase (decrease) in efficiency. In Table 3, the time trend estimate indicates that, ceteris paribus, banks' technical inefficiency continues to decrease at the rate of 9.6 percent per annum throughout the study period, showing that they are moving closer to their efficient frontier.

Our results suggest that private banks demonstrate the lowest level of cost-inefficiency (or highest level of cost-efficiency) compared with foreign and state-owned banks (see $\phi_{1}$ and $\phi_{2}$ ). The technical inefficiency of banks selected for privatization is no different from that of private banks. Burki and Ahmad (2010) note that there are two important factors that explain the relatively good performance of selected state-owned banks: first, the selected state-owned banks had undergone a preparatory and restructuring phase before being privatized; and second, relatively better performing banks are put up for sale because poorly performing stateowned banks cannot easily be sold to the private sector. The results in Table 3 further show that privatized banks experience different efficiency trends in the short run and long run, as indicated by changing parameter 
values for the $\phi_{3}, \phi_{6}$, and $\phi_{9}$ coefficients. Similarly, state-owned banks that were selected for restructuring also experience efficiency losses in the years after restructuring, but this trend is significantly reversed once these banks adjust to market conditions. This pattern can be observed from the magnitude and statistical significance of the parameter values for $\phi_{4}, \phi_{6}$, and $\phi_{10}$. Our results also indicate that (i) banks selected for M\&A are technically more inefficient than private banks, as shown by the positive and statistically significant $\phi_{5}$ coefficient, and (ii) following ownership change, these banks demonstrate lower technical inefficiency (see coefficients $\phi_{8}$ and $\phi_{11}$ ). If these trends continue, this group of banks is expected to hold on to the gains in technical efficiency even in the long run. For robustness checks, we also try alternative empirical specifications to separate the effects of each set of governance variables. The full model includes all governance change variables. We present each set of governance variables in a separate model in columns 2 to 5 of Table 3 for sensitivity analysis. In general, we find that the estimated coefficients of these models are robust across alternative models.

Table 2: Maximum Likelihood Parameter Estimates of Translog Stochastic Cost Frontier

\begin{tabular}{llllllr}
\hline Variables & $\begin{array}{c}\text { Para- } \\
\text { meters }\end{array}$ & $\begin{array}{c}\text { Full } \\
\text { Model }\end{array}$ & $\begin{array}{c}\text { Privatiza- } \\
\text { tion }\end{array}$ & $\begin{array}{c}\text { Restruc- } \\
\text { turing }\end{array}$ & $\begin{array}{c}\text { M\&A } \\
\text { Excluding } \\
\text { Years After } \\
\text { Governance } \\
\text { Change }\end{array}$ \\
\hline Constant & $\alpha_{0}$ & $0.448^{* * *}$ & $0.465^{* * *}$ & $0.456^{* * *}$ & $0.456^{* * *}$ & $0.478^{* * *}$ \\
& & $(11.65)$ & $(13.75)$ & $(14.16)$ & $(14.16)$ & $(13.77)$ \\
$\ln y_{1}$ & $\alpha_{1}$ & $0.488^{* * *}$ & $0.481^{* * *}$ & $0.489^{* * *}$ & $0.489^{* * *}$ & $0.486^{* * *}$ \\
& & $(15.94)$ & $(15.97)$ & $(16.29)$ & $(16.29)$ & $(16.40)$ \\
$\ln y_{2}$ & $\alpha_{2}$ & $0.532^{* * *}$ & $0.540^{* * *}$ & $0.534^{* * *}$ & $0.534^{* * *}$ & $0.537^{* * *}$ \\
& & $(17.04)$ & $(17.60)$ & $(17.21)$ & $(17.21)$ & $(17.55)$ \\
$\ln w_{1}$ & $\beta_{1}$ & $0.078^{* * *}$ & $0.082^{* * *}$ & $0.078^{* * *}$ & $0.078^{* * *}$ & $0.077^{* * *}$ \\
& & $(2.70)$ & $(2.84)$ & $(2.74)$ & $(2.74)$ & $(2.73)$ \\
$\ln w_{3}$ & $\beta_{3}$ & $0.247^{* * *}$ & $0.241^{* * * *}$ & $0.247^{* * *}$ & $0.247^{* * *}$ & $0.247^{* * *}$ \\
& & $(8.75)$ & $(8.66)$ & $(8.82)$ & $(8.82)$ & $(8.92)$ \\
$\tau$ & $\phi_{\tau}$ & $0.017^{* * *}$ & $0.015^{* *}$ & $0.011^{*}$ & $0.010^{*}$ & $0.013^{* *}$ \\
& & $(2.82)$ & $(2.50)$ & $(1.80)$ & $(1.80)$ & $(2.20)$ \\
$\tau^{2}$ & $\phi_{\tau \tau}$ & -0.0002 & -0.001 & -0.0004 & -0.0003 & -0.001 \\
& & $(-0.25)$ & $(-0.76)$ & $(-0.42)$ & $(-0.42)$ & $(-0.64)$ \\
$\ln y_{1}^{2}$ & $\alpha_{11}$ & $0.135^{* * *}$ & $0.130^{* * * *}$ & $0.134^{* * *}$ & $0.134^{* * *}$ & $0.133^{* * *}$ \\
& & $(15.77)$ & $(15.18)$ & $(15.79)$ & $(15.79)$ & $(15.99)$ \\
$\ln y_{2}^{2}$ & $\alpha_{22}$ & $0.136^{* * *}$ & $0.136^{* * *}$ & $0.136^{* * *}$ & $0.136^{* * *}$ & 0.137 \\
& & $(12.87)$ & $(12.91)$ & $(13.01)$ & $(13.01)$ & $(13.04)$ \\
\hline
\end{tabular}




\begin{tabular}{|c|c|c|c|c|c|c|}
\hline $\ln y_{1} \ln y_{2}$ & $\alpha_{12}$ & $\begin{array}{l}-0.110^{* * *} \\
(-12.04)\end{array}$ & $\begin{array}{l}-0.104^{* * *} \\
(-11.43)\end{array}$ & $\begin{array}{l}-0.108^{* * *} \\
(-11.81)\end{array}$ & $\begin{array}{l}-0.108^{* * *} \\
(-11.81)\end{array}$ & $\begin{array}{r}-0.108^{* * * *} \\
(-12.03)\end{array}$ \\
\hline $\ln w_{1}^{2}$ & $\beta_{11}$ & $\begin{array}{l}0.008 \\
(0.46)\end{array}$ & $\begin{array}{l}0.007 \\
(0.41)\end{array}$ & $\begin{array}{l}0.009 \\
(0.52)\end{array}$ & $\begin{array}{l}0.009 \\
(0.52)\end{array}$ & $\begin{array}{l}0.002 \\
(0.14)\end{array}$ \\
\hline $\ln w_{3}^{2}$ & $\beta_{33}$ & $\begin{array}{l}-0.026 \\
(-1.18)\end{array}$ & $\begin{array}{l}-0.028 \\
(-1.24)\end{array}$ & $\begin{array}{l}-0.028 \\
(-1.24)\end{array}$ & $\begin{array}{l}-0.028 \\
(-1.24)\end{array}$ & $\begin{array}{l}-0.035 \\
(-1.54)\end{array}$ \\
\hline $\ln w_{1} \ln w_{3}$ & $\beta_{13}$ & $\begin{array}{l}-0.031 \\
(-1.53)\end{array}$ & $\begin{array}{l}-0.024 \\
(-1.21)\end{array}$ & $\begin{array}{l}-0.030 \\
(-1.49)\end{array}$ & $\begin{array}{l}-0.030 \\
(-1.49)\end{array}$ & $\begin{array}{l}-0.022 \\
(-1.09)\end{array}$ \\
\hline $\ln w_{1} \ln y_{1}$ & $\gamma_{11}$ & $\begin{array}{l}0.016 \\
(1.16)\end{array}$ & $\begin{array}{l}0.014 \\
(1.01)\end{array}$ & $\begin{array}{l}0.013 \\
(0.98)\end{array}$ & $\begin{array}{l}0.013 \\
(0.98)\end{array}$ & $\begin{array}{l}0.015 \\
(1.07)\end{array}$ \\
\hline $\ln w_{3} \ln y_{1}$ & $\gamma_{31}$ & $\begin{array}{l}0.005 \\
(0.28)\end{array}$ & $\begin{array}{l}0.006 \\
(0.36)\end{array}$ & $\begin{array}{l}0.008 \\
(0.47)\end{array}$ & $\begin{array}{l}0.008 \\
(0.47)\end{array}$ & $\begin{array}{l}0.006 \\
(0.32)\end{array}$ \\
\hline $\ln w_{1} \ln y_{2}$ & $\gamma_{12}$ & $\begin{array}{l}-0.063^{* * *} \\
(-3.88)\end{array}$ & $\begin{array}{l}-0.064^{* * *} \\
(-3.94)\end{array}$ & $\begin{array}{l}-0.062^{* * *} \\
(-3.86)\end{array}$ & $\begin{array}{l}-0.062^{* * *} \\
(-3.86)\end{array}$ & $\begin{array}{r}-0.064^{* * *} \\
(3.95)\end{array}$ \\
\hline $\ln w_{3} \ln y_{2}$ & $\gamma_{32}$ & $\begin{array}{l}0.014 \\
(0.86)\end{array}$ & $\begin{array}{l}0.010 \\
(0.60)\end{array}$ & $\begin{array}{l}0.011 \\
(0.66)\end{array}$ & $\begin{array}{l}0.011 \\
(0.66)\end{array}$ & $\begin{array}{l}0.014 \\
(0.86)\end{array}$ \\
\hline $\ln y_{1} \tau$ & $\gamma_{1 \tau}$ & $\begin{array}{l}0.003 \\
(0.69)\end{array}$ & $\begin{array}{l}0.004 \\
(0.92)\end{array}$ & $\begin{array}{l}0.003 \\
(0.68)\end{array}$ & $\begin{array}{l}0.003 \\
(0.68)\end{array}$ & $\begin{array}{l}0.003 \\
(0.86)\end{array}$ \\
\hline $\ln y_{2} \tau$ & $\gamma_{2 \tau}$ & $\begin{array}{l}0.009^{* *} \\
(2.01)\end{array}$ & $\begin{array}{l}0.009^{* *} \\
(2.07)\end{array}$ & $\begin{array}{l}0.008^{* *} \\
(1.98)\end{array}$ & $\begin{array}{l}0.008^{* *} \\
(1.98)\end{array}$ & $\begin{array}{r}0.008^{* *} \\
(1.96)\end{array}$ \\
\hline $\ln w_{1} \tau$ & $\delta_{1 \tau}$ & $\begin{array}{l}0.005 \\
(0.10)\end{array}$ & $\begin{array}{l}0.009^{*} \\
(1.65)\end{array}$ & $\begin{array}{l}0.006 \\
(1.12)\end{array}$ & $\begin{array}{l}0.006 \\
(1.13)\end{array}$ & $\begin{array}{l}0.007 \\
(1.31)\end{array}$ \\
\hline $\ln w_{3} \tau$ & $\delta_{2 \tau}$ & $\begin{array}{l}-0.005 \\
(0.098)\end{array}$ & $\begin{array}{l}-0.009^{*} \\
(-1.72)\end{array}$ & $\begin{array}{l}-0.008 \\
(-1.37)\end{array}$ & $\begin{array}{l}-0.008 \\
(-1.37)\end{array}$ & $\begin{array}{l}-0.007 \\
(-1.31)\end{array}$ \\
\hline$\sigma^{2}=\sigma_{v}^{2}+\sigma_{v}^{2}$ & - & $\begin{array}{l}0.445^{* * *} \\
(6.74)\end{array}$ & $\begin{array}{l}0.648^{* * *} \\
(4.54)\end{array}$ & $\begin{array}{l}0.477^{* * *} \\
(5.79)\end{array}$ & $\begin{array}{l}0.477^{* * *} \\
(5.79)\end{array}$ & $\begin{array}{r}0.864^{* * * *} \\
(5.74)\end{array}$ \\
\hline$\gamma=\sigma_{v}^{2} /\left(\sigma_{v}^{2}+\sigma_{v}^{2}\right)$ & - & $\begin{array}{l}0.880^{* * *} \\
(34.97)\end{array}$ & $\begin{array}{l}0.911^{* * *} \\
(37.77)\end{array}$ & $\begin{array}{l}0.882^{* * * *} \\
(33.54)\end{array}$ & $\begin{array}{l}0.882^{* * *} \\
(33.54)\end{array}$ & $\begin{array}{r}0.935^{* * * *} \\
(66.17)\end{array}$ \\
\hline Log likelihood & - & -149.311 & -150.615 & -152.243 & -153.634 & -145.981 \\
\hline Mean efficiency & - & 1.350 & 1.329 & 1.336 & 1.333 & 1.320 \\
\hline No. of observations & $N$ & 520 & 520 & 520 & 520 & 520 \\
\hline
\end{tabular}

Note: ${ }^{*}, *$, and ${ }^{* * *}$ indicate statistical significance at the 90 percent, 95 percent, and 99 percent confidence levels, respectively. 
Table 3: Maximum Likelihood Parameter Estimates of Inefficiency Effects Model

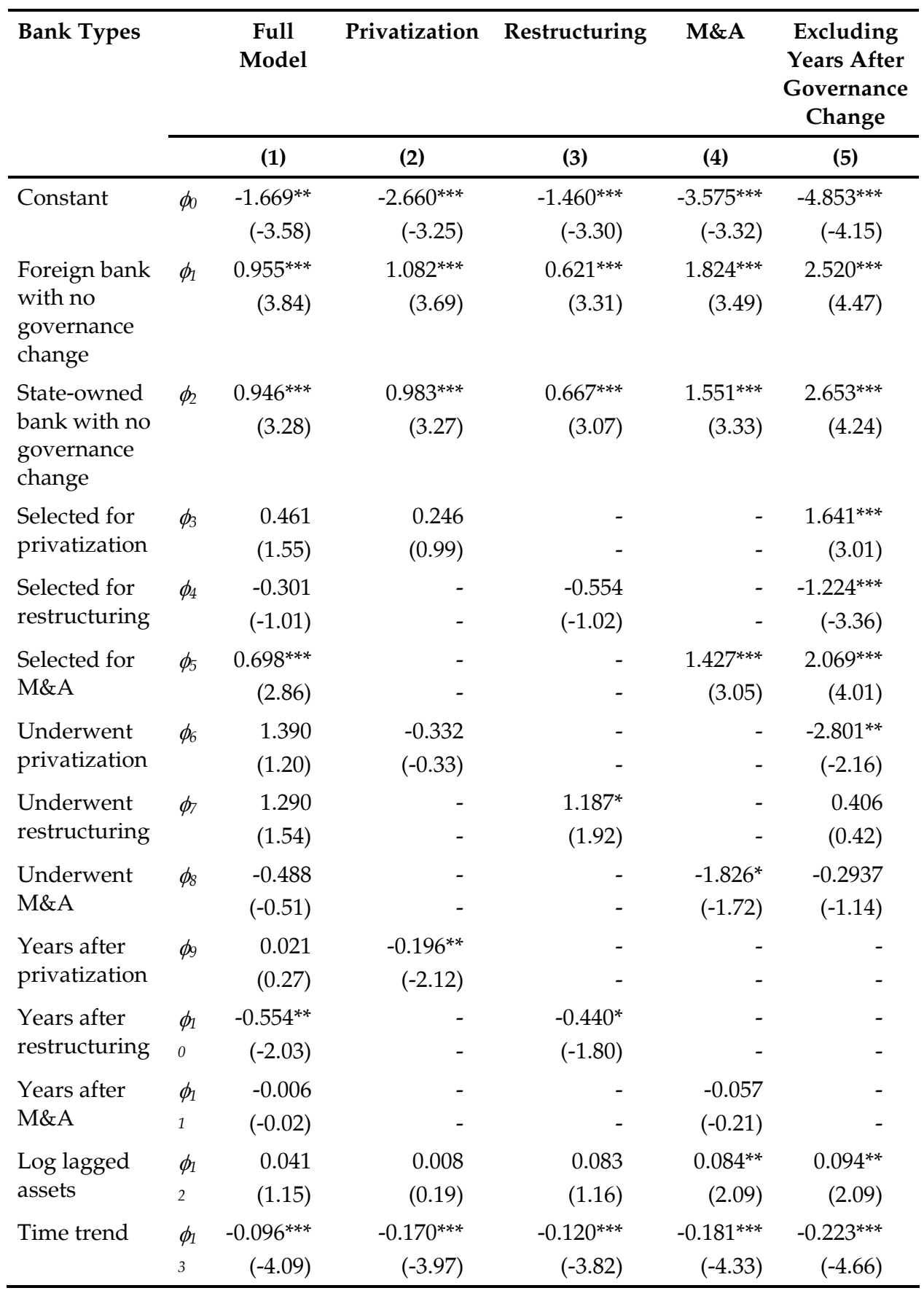

Note: ${ }^{*}, * *$, and ${ }^{* * *}$ indicate statistical significance at the 90 percent, 95 percent, and 99 percent confidence levels, respectively. 


\section{TFPC and its Decomposition}

Next, we decompose TFPC into its components, using parametric estimates of the translog cost frontier in Equation (3). First, we compare the TFP components CEC, TC, and SEC, and then account for AEC. Table 4 provides descriptive statistics for TFPC and its components for the entire bank sample as well as for different types of bank ownership.

Table 4: Mean Values of Average TFP Components

\begin{tabular}{lllllllll}
\hline Bank Type & Descriptors & CEC & TC & SEC & TFPC & AEC & TFPC1 & CE \\
\hline All & N & 475 & & & & & & \\
& Mean & 0.02 & 1.36 & -0.02 & 1.37 & 0.06 & 1.43 & 0.792 \\
& Minimum & -1.37 & -5.20 & -18.02 & -16.66 & -12.91 & -13.79 & 0.150 \\
Foreign & Maximum & 2.12 & 7.15 & 33.05 & 36.71 & 18.40 & 40.87 & 0.950 \\
& N & 224 & & & & & & \\
& Mean & 0.03 & 2.05 & 0.05 & 2.14 & 0.03 & 2.17 & 0.787 \\
\multirow{5}{*}{ Private } & Minimum & -1.32 & -2.41 & -18.02 & -16.66 & -12.91 & -13.79 & 0.140 \\
& Maximum & 2.12 & 5.82 & 33.05 & 36.71 & 18.40 & 40.87 & 0.955 \\
& N & 160 & & & & & & \\
& Mean & 0.002 & 1.34 & -0.01 & 1.33 & 0.11 & 1.44 & 0.807 \\
& Minimum & -0.52 & -3.11 & -13.82 & -12.27 & -13.82 & -13.43 & 0.380 \\
& Maximum & 0.47 & 7.15 & 20.11 & 23.37 & 20.11 & 21.63 & 0.952 \\
& N & 90 & & & & & & \\
& Mean & 0.17 & 0.05 & -0.20 & 0.02 & 0.05 & 0.07 & 0.772 \\
& Minimum & -1.37 & -5.20 & -9.91 & -10.60 & -3.04 & -9.49 & 0.277 \\
& Maximum & 1.50 & 4.87 & 13.16 & 16.55 & 2.65 & 15.26 & 0.952 \\
\hline
\end{tabular}

Note:TFPC $C_{n}=C E C_{n}+T C_{n}+S E C_{n} ; T_{F P C}^{*}=C E C_{n}+T C_{n}+S E C_{n}+A E C_{n}$

The results in Table 4 indicate that TFP in the banking sector increased by 1.37 percent during 1992-2005. However, the potential TFP increases to 1.47 percent when we account for AEC over the same period. The major contributing factor in TFPC is the change in technology (TC), which increased by 1.36 percent on average. We also find that CEC remains fairly stable during the entire study period. Surprisingly, scale effects contribute negatively to TFPC, indicating that the banking industry experienced diseconomies of scale during the study period.

The results for TFPC by bank ownership also suggest positive growth where foreign banks show, on average, an annual TFPC of about 
2.14 percent. This could have increased further had banks adjusted for allocative efficiency. Foreign banks post the highest average annual TFPC (2.14 percent), followed by private banks (1.33 percent), and then public banks.

The TFPC of foreign banks could have increased further to 2.17 percent by removing distortions in the input and output mix. The productivity growth of private banks is accounted for mostly by changes in technology (1.34 percent). Private banks also remain more successful in overcoming allocative inefficiencies (perhaps due to competition policies introduced during the reforms process), which significantly contribute to TFPC (0.11 percent). While public banks show a modest increase in TFP (0.02 percent), they appear to be catching up to the technological levels of foreign and private banks, as indicated by the 0.17 percent change in cost efficiency, which is significantly higher than that of private and foreign banks. However, new technology and innovations (TC) plays a key role in the TFPC of private and foreign banks, which is not the case for public banks. Scale economies contribute negatively to the TFPC of public and private banks, which could be explained by the large-scale restructuring, downsizing, and branch closure of certain public banks.

Figures 1 and 2 provide further insights into the patterns of TFPC and its components on a year-by-year basis. For example, Figure 1 illustrates the trend followed by TFPC and its components by bank ownership. We note that TFPC remains positive for the study period but presents a volatile trend across different periods. Figure 1(a) portrays the trend followed by TFPC for all banks, where changes in TFP and its components remain positive throughout, but show a declining trend. These fluctuations could be attributed to financial sector reforms. 
Figure 1: TFP Decomposition into Components without AEC a: All banks

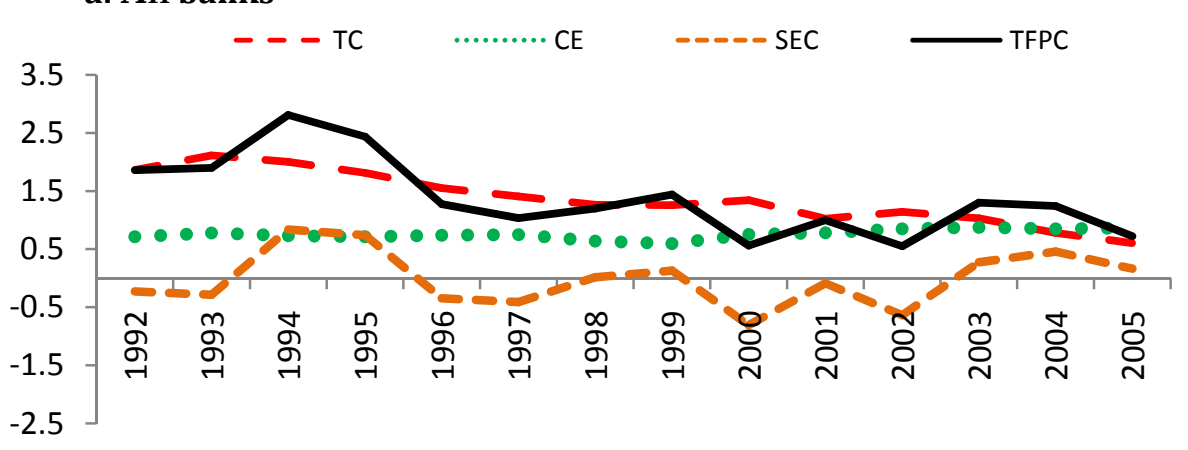

b: Foreign banks

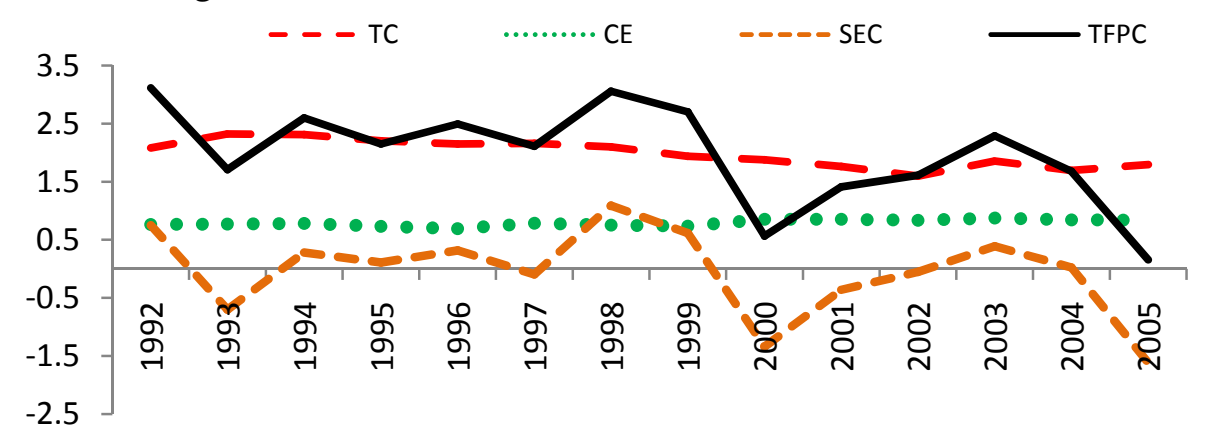

c: Private banks

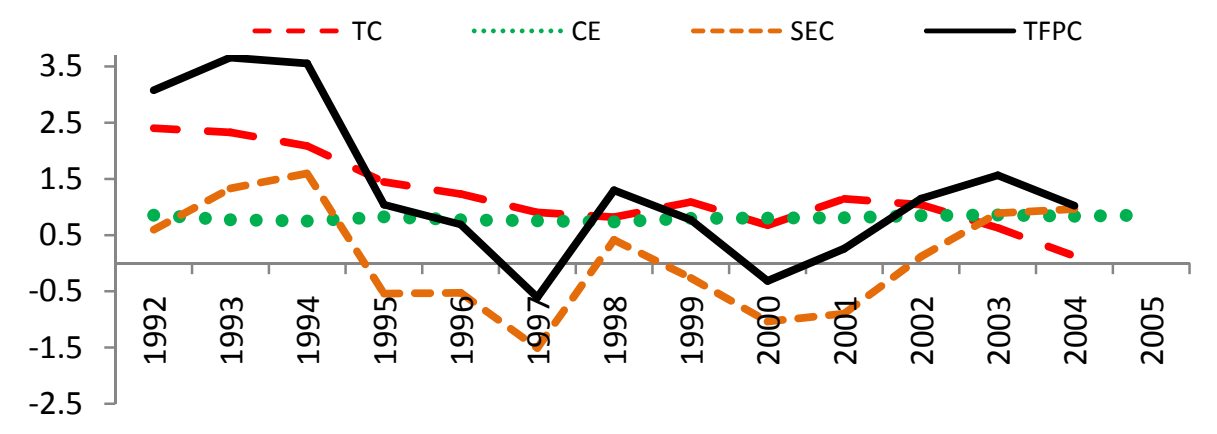




\section{d: Public banks}

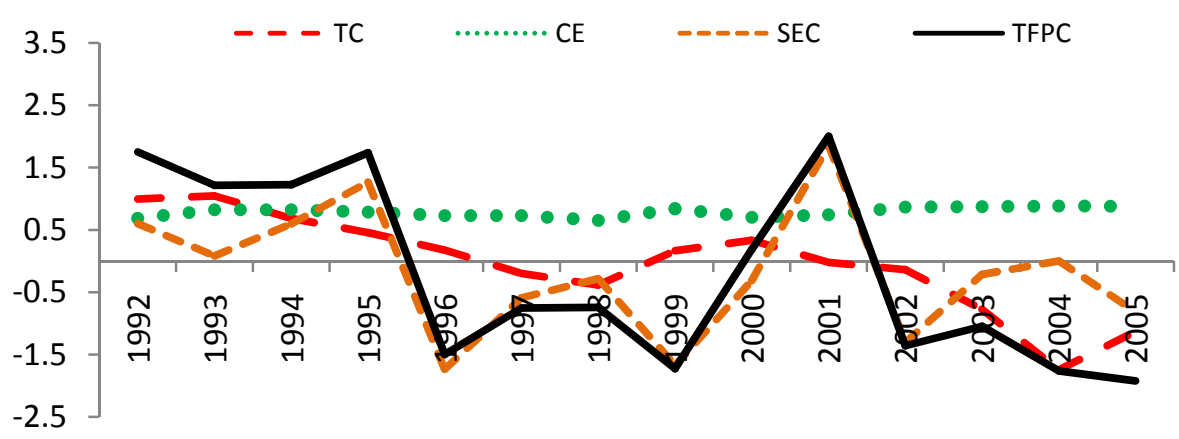

Note: $\mathrm{AEC}=$ allocative efficiency change, $\mathrm{CE}=$ cost efficiency, $\mathrm{SEC}=$ scale efficiency change, $\mathrm{TC}=$ technical change, TFPC $1=$ total factor productivity change while accounting for allocative efficiency. 
Figure 2: TFP Decomposition into Components with AEC

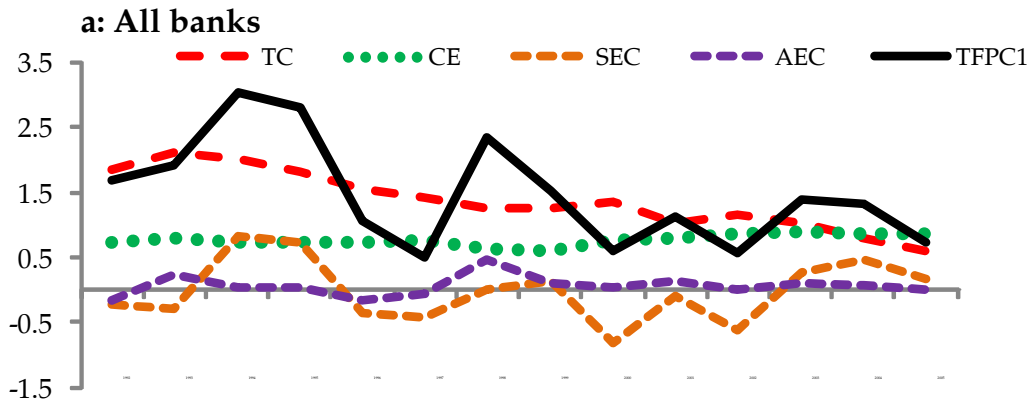

b: Foreign banks

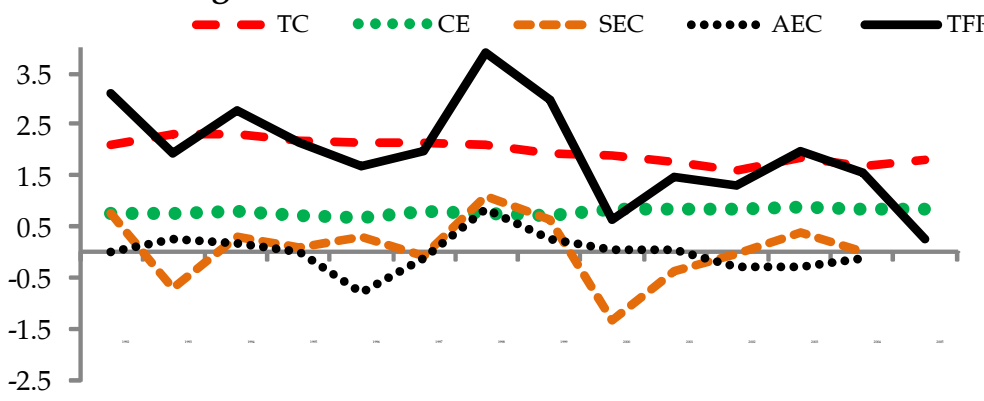

c: Private banks

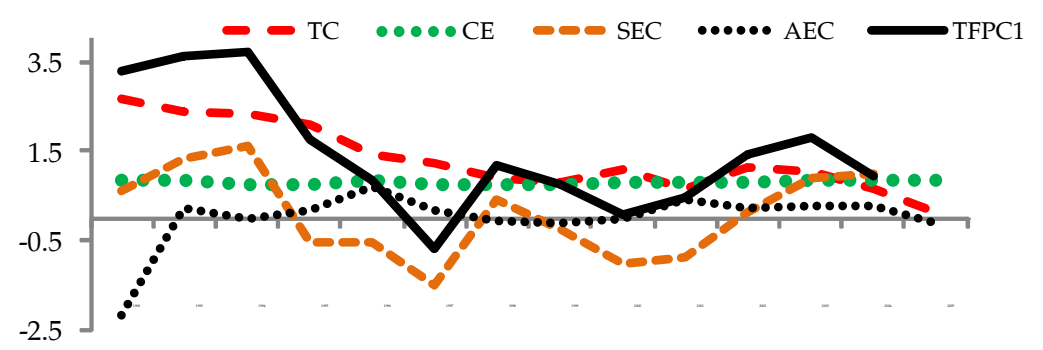

d: Public banks

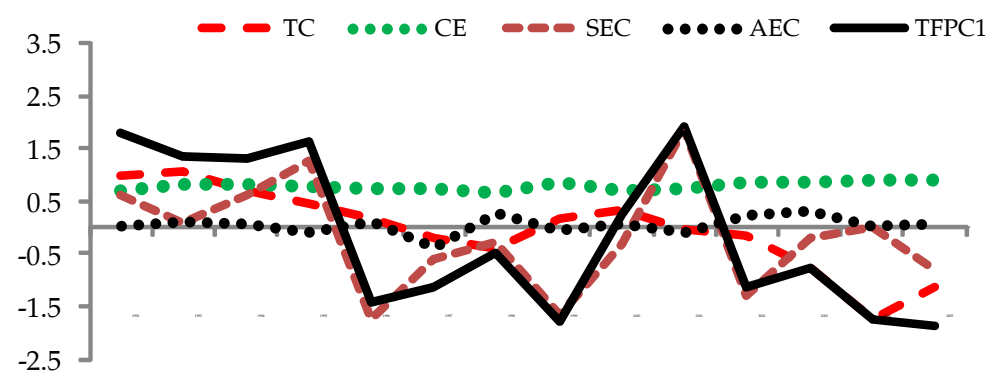

Note: $\mathrm{AEC}=$ allocative efficiency change $\mathrm{CE}=$ cost efficiency, $\mathrm{SEC}=$ scale efficiency change, TC $=$ technical change, TFPC $1=$ total factor productivity change without accounting for allocative efficiency. 


\section{TFPC by Bank Governance Variables}

How have changes in bank governance impacted banks' performance? Table 5 presents patterns for TFPC and its components for our governance change variables. On average, foreign banks that underwent governance change exhibit higher TFP growth vis-à-vis those that did not experience any governance change. 4 For instance, foreign banks with governance change show an average TFP growth rate of 2.31 percent, compared to banks with no governance change (2.05 percent). This change in TFP is explained by changes in technology. TFPC increases further to 2.46 percent when AEC is also accounted for. State-owned banks with no governance change exhibit, on average, a negative growth rate for TFP (-0.37 percent) while those that underwent a governance change show a slight increase in TFP growth (0.18 percent). These results are consistent with the findings reported in Table 3.

Table 5: Decomposition of TFPC for Different Governance Changes

\begin{tabular}{lcccccc}
\hline Description & CEC & TC & SEC & TFPC & AEC & TFPC1 \\
\hline Foreign banks with no governance change & 0.04 & 1.64 & 0.36 & 2.05 & 0.01 & 2.06 \\
Foreign banks with governance change & 0.01 & 2.57 & -0.27 & 2.31 & 0.14 & 2.46 \\
Public banks with no governance change & 0.02 & -0.24 & -0.15 & -0.37 & 0.13 & -0.24 \\
Public banks with governance change & 0.01 & 0.49 & -0.33 & 0.18 & 0.05 & 0.22 \\
Selected for privatization & 0.02 & -0.70 & 0.02 & -0.66 & 0.02 & -0.64 \\
Selected for restructuring & 0.02 & -1.00 & -0.09 & -1.07 & -0.02 & -1.08 \\
Selected for M\&A & 0.17 & 4.54 & 0.03 & 4.74 & 0.50 & 5.24 \\
\hline
\end{tabular}

We also find that public banks selected for privatization experienced negative TFP growth before they were privatized, as did banks selected for restructuring. However, banks selected for M\&A exhibit positive TFP growth: an average of 4.74 percent per annum, driven mostly by technological changes. Both CEC and SEC contribute marginally to the increase in TFP.

Figure 3 illustrates these results by comparing TFPC by governance change variables. Figures 3(a) and 3(b) compare the TFPC of foreign banks, indicating that foreign banks that underwent governance change show an improved TFP compared with banks that did not undergo governance change. The trend followed by state-owned banks also shows that governance change introduced an upward trend in TFPC [Figures 3(c) and

\footnotetext{
${ }^{4}$ Since our sample of private banks with governance changes is quite small, and may not accurately represent these changes, we have not computed TFPCs for these banks.
} 
3(d)]. This increase in TFP appears to have taken place after 1999, which could be a result of different steps taken by the government to strengthen these banks, e.g., the liquidation of state-owned banks by injecting more liquidity. Similarly, Figures 4(a) to 4(d) illustrate the effects of governance change on these banks' productivity trends.

Finally, Figures 5(a) to 5(c) depict the pattern of productivity change due to selection effects. Banks selected for privatization and restructuring experienced a negative change in TFP until 2000, and a fluctuating pattern thereafter. However, banks that underwent M\&A show an increasing trend in TFPC along with its components [Figure 5(c)].

Figure 3: TFP Decomposition for Banks with and without Governance Change Component without AEC

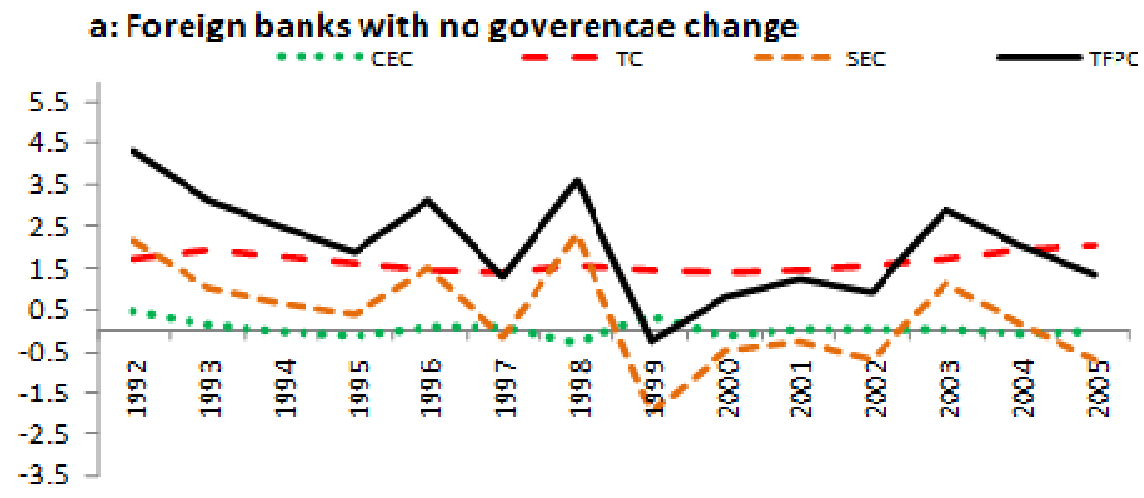

b: Foreign banks with goverencae change

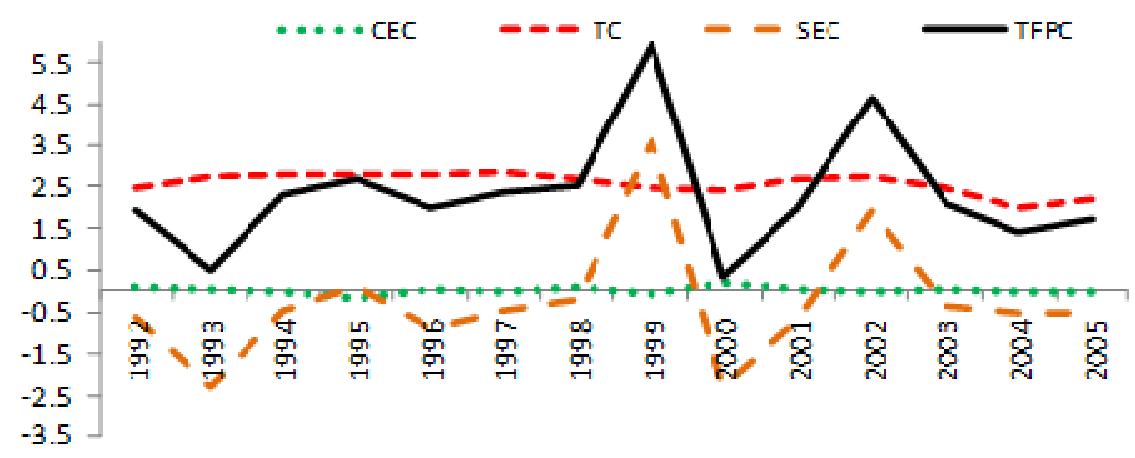


ci State-owned banks with no governace change

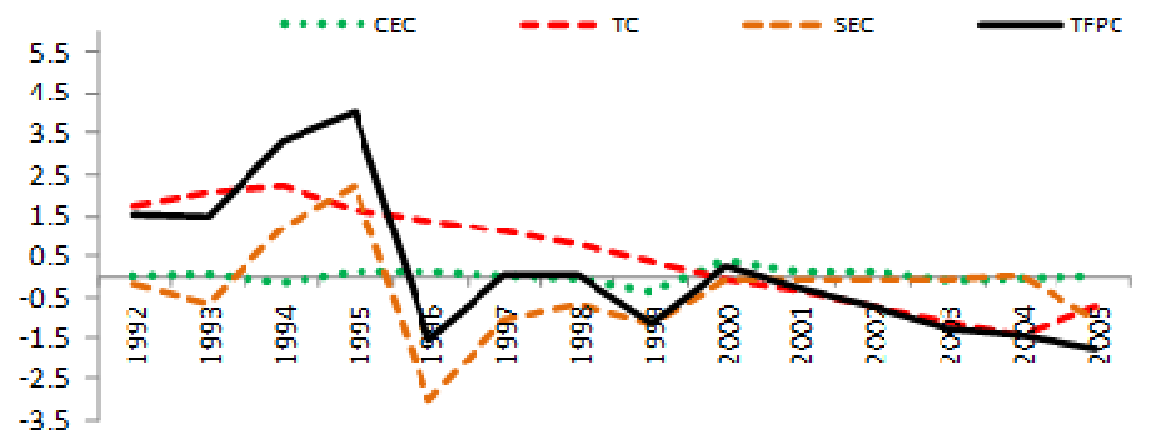

d: State-owned banks with governace change

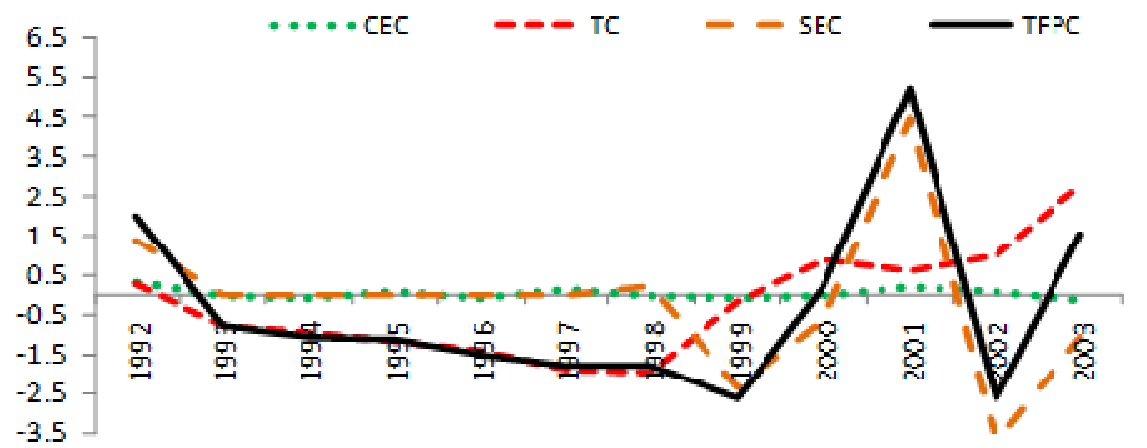


Figure 4: TFP Decomposition for Banks with and without Governance Change Component without AEC

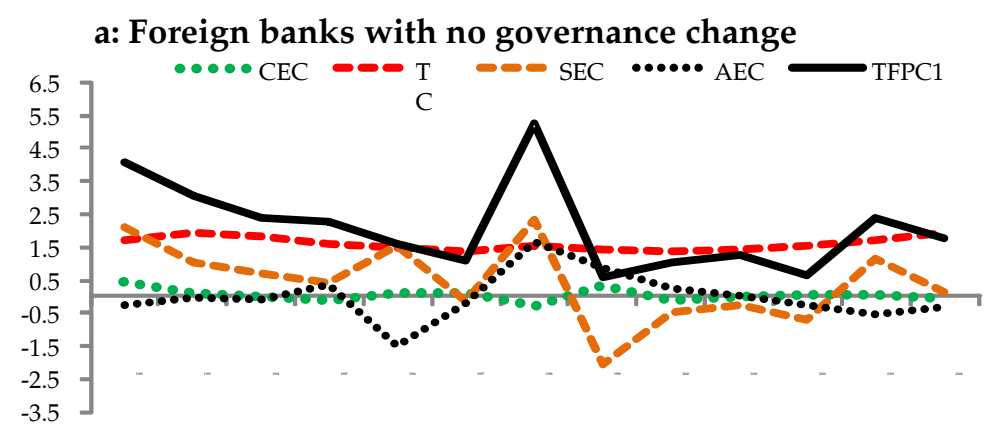

b: Foreign banks with governance change
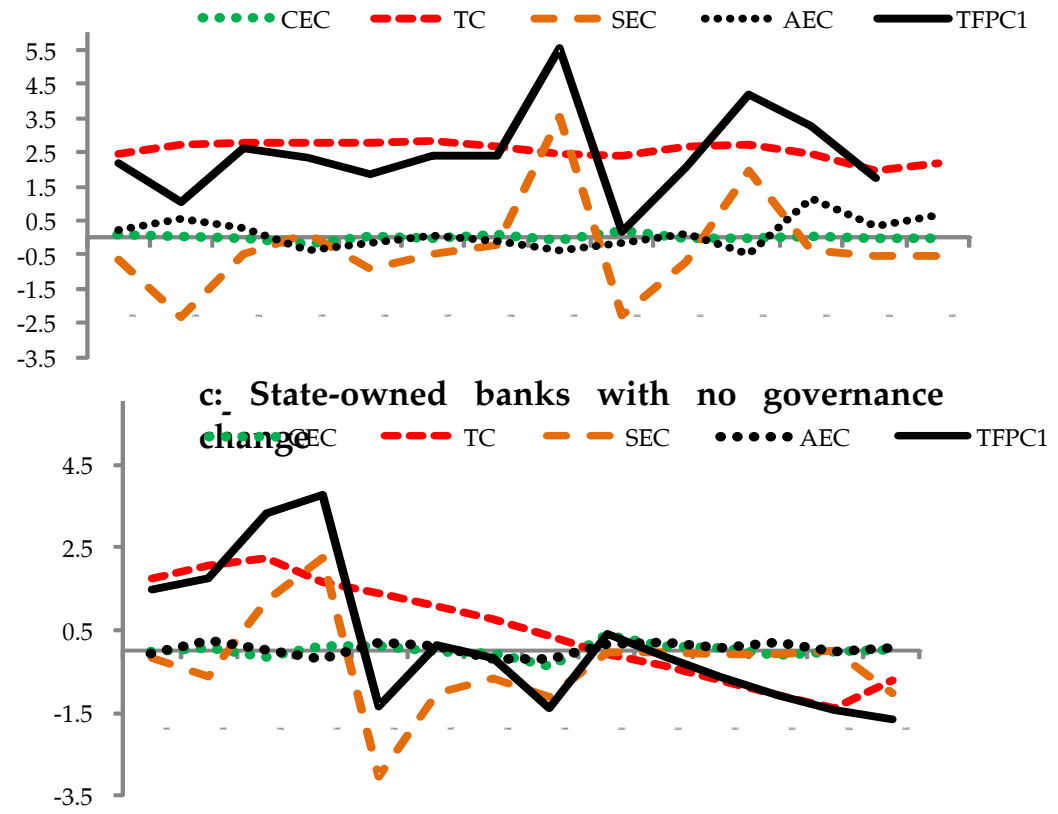

d: State-owned banks with governance change

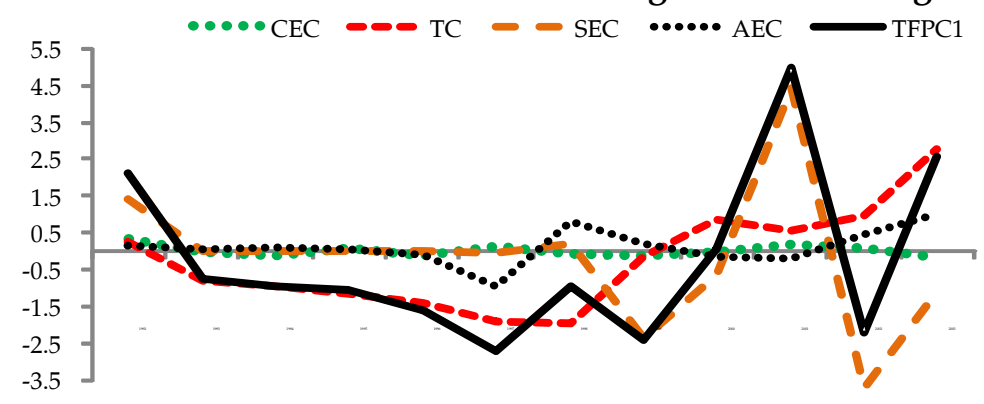


Figure 5: TFP Decomposition for Banks with Selection Effects with AEC

a: Selected for privatization

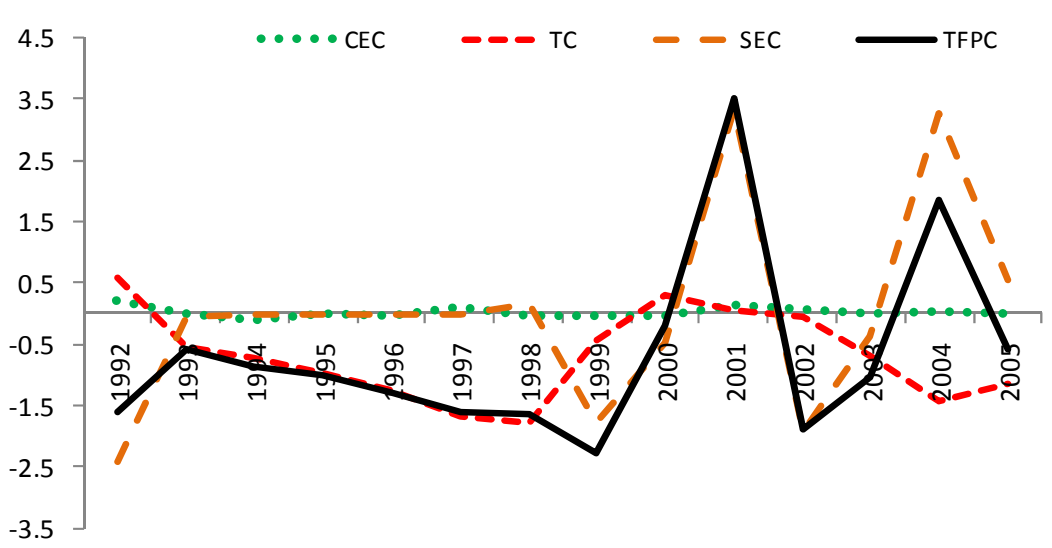

b: Selected for restructuring

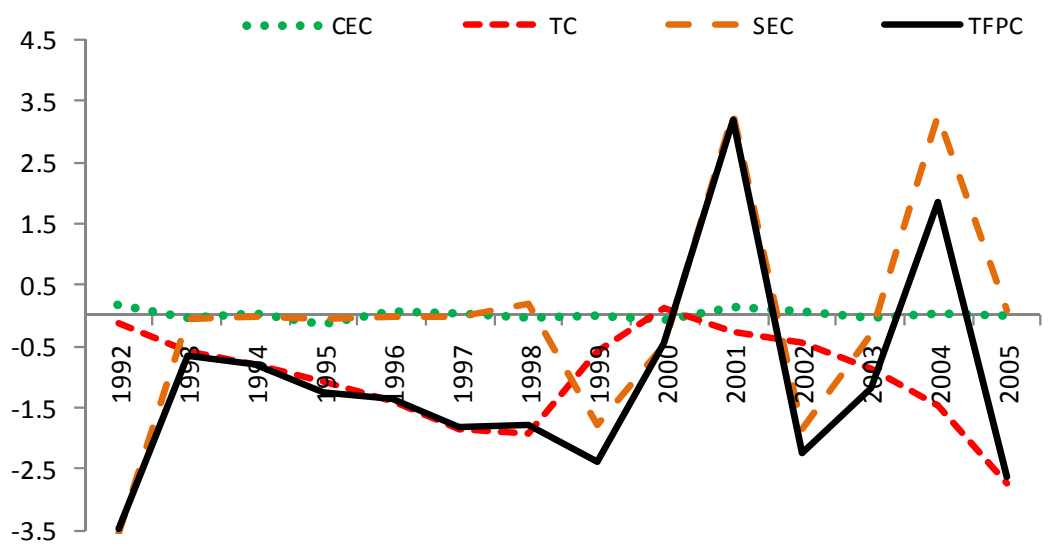

c: Selected for M\&A

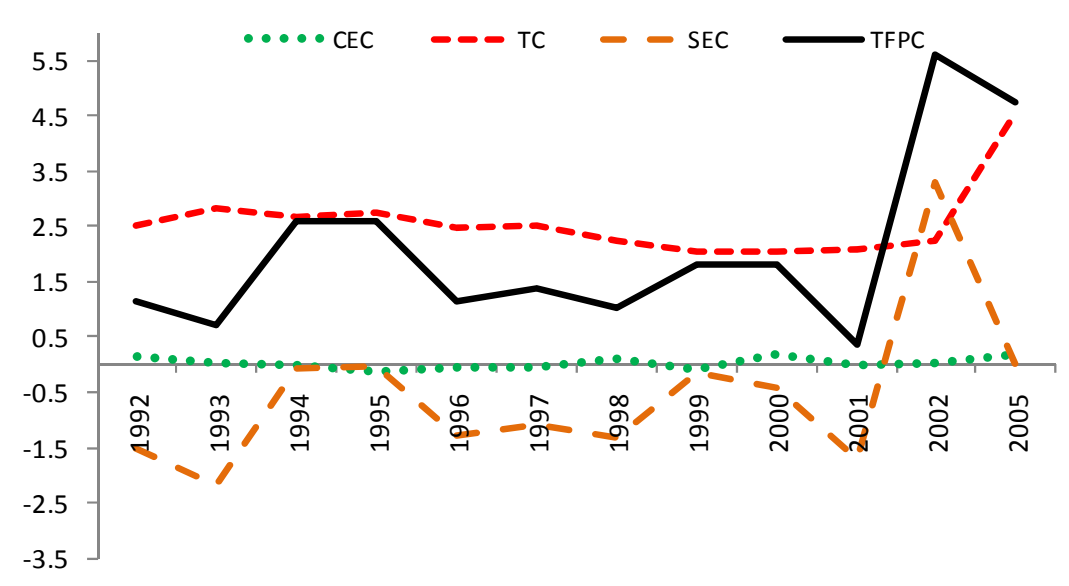




\section{Concluding Observations}

This paper has extended the results of Burki and Ahmad (2010) by calculating TFPC and its decompositions by bank ownership and bank governance change indicators. In general, our results have shown that the technical inefficiency of banks was 35 percent during the study period, indicating that the cost of production of these banks exceeded their minimum cost frontier. However, this inefficiency decreased at a rate of 9.6 percent per annum. On average, private banks demonstrated greater technical efficiency than foreign and state-owned banks. The technical inefficiency of banks selected for privatization was not different from that of private banks. Privatized banks experienced different efficiency trends in the short and long run. State-owned banks that were selected for restructuring experienced efficiency losses in the years following restructuring, but this trend was significantly reversed after these banks adjusted to market conditions. Our results have also shown that banks selected for M\&A were technically less efficient than private banks, and that, following ownership change, these banks demonstrated improved technical efficiency. If these trends continue, this group of banks is expected to hold on to the gains in technical efficiency even in the long run.

We have also found that most of the TFPC in Pakistan's banking sector was driven by technical change. The declining trend in TFP growth could be an indication of the increasing profitability of the banking sector. Surprisingly, the magnitude of scale effects remain insignificant despite the increased outreach of banking services, which might have been offset by diseconomies of scale since the banking sector was operating on an increasing cost frontier while experiencing different reforms. Banks that underwent a governance change showed an improvement in TFP growth and its components vis-à-vis those banks that were not selected for governance change. Both foreign and state-owned banks that underwent a governance change showed an increasing trend in TFPC as compared to banks that did not experience any governance change. Finally, selection variables brought about partial effects by bank ownership, while the more significant effects were related to bank consolidation. 


\section{References}

Bauer, P. W., Berger, A. N., \& Humphrey, D. B. (1993). Efficiency and productivity growth in US banking. In H. O. Fried, C. A. K. Lovell, \& S. S. Schmidt (Eds.), The measurement of productive efficiency. New York, NY: Oxford University Press.

Berger, A. N., \& Mester, L. J. (1997). Inside the black box: What explains differences in the efficiencies of financial institutions? Journal of Banking and Finance, 21, 895-947.

Berger, A. N., \& Mester, L. J. (2003). Explaining the dramatic change in performance of US banks: Technological change, deregulation, and dynamic changes in competition. Journal of Financial Intermediation, 12, 57-95.

Berger, A. N., Clarke, G. R. G., Cull, R., Klapper, L., \& Udell, G. F. (2005). Corporate governance and bank performance: A joint analysis of static, selection, and dynamic effects of domestic, foreign and state ownership. Journal of Banking and Finance, 29, 2179-2221.

Berger, A. N., Hanweck, G. A., \& Humphrey, D. B. (1987). Competitive viability in banking: Scale, scope, and product mix economies. Journal of Monetary Economics, 20, 501-520.

Berger, A. N., \& Humphrey, D. B. (1997). Efficiency of financial institutions: International survey and directions for future research. European Journal of Operational Research, 98, 175-212.

Bhattacharya, A., Lovell, C. A. K., \& Sahay, P. (1997). The impact of liberalization on the productive efficiency of Indian commercial banks. European Journal of Operational Research, 98, 332-345.

Boubakri, N., Cosset, J.-C., \& Guedhami, O. (2005). Liberalization, corporate governance, and the performance of privatized firms in developing countries. Journal of Corporate Finance, 11, 767-790.

Burki, A. A., \& Niazi, G. S. K. (2010). Impact of financial reforms on efficiency of state-owned, private and foreign banks in Pakistan. Applied Economics, 42, 3147-3160. 
Burki, A. A., \& Ahmad, S. (2010). Bank governance changes in Pakistan: Is there a performance effect? Journal of Economics and Business, 62(2), 129-146.

Clarke, G. R. G., Cull, R., \& Shirley, M. M. (2005). Bank privatization in developing countries: A summary of lessons and findings. Journal of Banking and Finance, 29, 1905-1930.

Coelli, T. J. (1996). A guide to FRONTIER version 4.1: A computer program for stochastic frontier production and cost function estimation (Working Paper No. 7). Armidale, Australia: Centre for Efficiency and Productivity Analysis, University of New England.

Coelli, T. J., Prasada Rao, D. S., \& Battese, G. E. (2005). An introduction to efficiency and productivity analysis. Boston, MA: Kluwer Academic Publishers.

Cuesta, R. A., \& Orea, L. (2002). Mergers and technical efficiency in Spanish savings banks: A stochastic distance function approach. Journal of Banking and Finance, 26, 2231-2247.

Drake, L., \& Weyman-Jones, T. G. (1996). Productive and allocative inefficiencies in UK building societies: A comparison of nonparametric and stochastic frontier techniques. Manchester School of Economic and Social Studies, 114, 22-37.

Fries, S., \& Taci, A. (2005). Cost efficiency of banks in transition: Evidence from 289 banks in 15 post-communist countries. Journal of Banking and Finance, 29, 55-81.

Gilbert, R. A., \& Wilson, P. W. (1998). Effects of deregulation on the productivity of Korean banks. Journal of Economics and Business, 50, 133-155.

Grifell-Tatjé, E., \& Lovell, C. A. K. (1996). Deregulation and productivity decline: The case of Spanish savings banks. European Economic Review, 40, 1281-1303.

Hao, J., Hunter, W. C., \& Yang, W. (2001). Deregulation and efficiency: The case of private Korean banks. Journal of Economics and Business, 53(2/3), 237-254. 
Hasan, I., \& Marton, K. (2003). Development and efficiency of the banking sector in a transitional economy. Journal of Banking and Finance, 27, 2249-2271.

Hughes, J. P., Lang, W., Mester L. J., \& Moon, C. (1999). Recovering risky technologies using the almost ideal demand system: An application to US banks. Journal of Financial Services Research, 18, 5-27.

Humphrey, D. B. (1993). Cost and technical change: Effects from bank deregulation. Journal of Productivity Analysis, 4, 9-34.

Humphrey, D. B., \& Pulley L. B. (1997). Banks' responses to deregulation: Profits, technology and efficiency. Journal of Money, Credit and Banking, 29, 73-93.

Isik, I., \& Hassan, M. K. (2002). Technical, scale and allocative efficiencies of Turkish banking industry. Journal of Banking and Finance, 26, 719-766.

Katib, M. N., \& Mathews, K. (2000). A non-parametric approach to efficiency measurement in the Malaysian banking sector. Singapore Economic Review, 44, 89-114.

Kodde, D. A., \& Palm, F. C. (1986). Wald criteria for jointly testing equality and inequality restrictions. Econometrica, 54, 1243-1248.

Leightner, J. E., \& Lovell, C. A. K. (1998). The impact of financial liberalization on the performance of Thai banks. Journal of Economics and Business, 50, 115-131.

Lensink, R., Meesters, A., \& Naaborg, I. (2008). Bank efficiency and foreign ownership: Do good institutions matter? Journal of Banking and Finance, 32, 834-844.

Mertens, A., \& Urga, G. (2001). Efficiency, scale and scope economies in the Ukrainian banking sector in 1998. Emerging Markets Review, 3(2), 292-308.

Mukherjee, K., Ray, S. C., \& Miller, S. M. (2001). Productivity growth in large US commercial banks: The initial post-deregulation experience. Journal of Banking and Finance, 25, 913-939. 
Okuda, H., \& Mieno, F. (1999). What happened to Thai commercial banks in the pre-Asian crisis period: Microeconomic analysis of Thai banking industry. Journal of Economics, 40, 12-97.

Opiela, T. P. (2001). Assessing the efficiency of Polish commercial banks (Working Paper). Warsaw: National Bank of Poland.

Patti, E. B., \& Hardy, D. C. (2005). Financial sector liberalization, bank privatization, and efficiency: Evidence from Pakistan. Journal of Banking and Finance, 29, 2381-2406.

Rezvanian, R., \& Mehdian, S. (2002). An examination of cost structure and production performance of commercial banks in Singapore. Journal of Banking and Finance, 26, 79-98.

State Bank of Pakistan. (2003). Pakistan financial sector assessment 19902000. Karachi: State Bank of Pakistan.

State Bank of Pakistan. (2005). Pakistan financial sector assessment 2004. Karachi: State Bank of Pakistan.

Sealey, C. W., \& Lindley, J. T. (1977). Inputs, outputs, and a theory of production and cost at depository financial institutions. Journal of Finance, 32, 1251-1265.

Williams, J., \& Nguyen, N. (2005). Financial liberalization, crisis, and restructuring: A comparative study of bank performance and bank governance in South Asia. Journal of Banking and Finance, 29, 2119-2154.

Williams, J., \& Intarachote, T. (2002). Financial liberalization and profit efficiency in the Thai banking system, 1990-1997: The case of domestic and foreign banks (Working Paper). Bangor, UK: University of Wales.

Yildrim, S. H., \& Philippatos, C. G. (2007). Restructuring and competition in Latin American banking markets. Journal of Banking and Finance, 31, 629-639. 